\title{
Ortopedi ve travmatolojide kullanılan implantların CE belgelendirilmesi
}

\section{CE certification of implants used in orthopedics and traumatology}

\author{
Ahmed Heydar ${ }^{1}$, Serdar Şirazi ${ }^{2}$ \\ 'Sağlık Bilimleri Üniversitesi, Derince Eğitim ve Araştırma Hastanesi, Ortopedi ve Travmatoloji Kliniği, Kocaeli \\ ${ }^{2}$ Ortopedi ve Travmatoloji Uzmanı - Hukukçu; Özel Avcılar Anadolu Hastanesi - Şahin Avukatlık Bürosu, İstanbul
}

Tıbbi cihaz ile ilacı ayıran en önemli kriterlerden birisi ilacın kimyasal etkisinin olması, cihazın ise mekanik etkisinin olmasıdır. Ortopedi ve travmatolojide kullanılan implantlar ve cerrahi aletler de mevcut tanıma girdiği için tıbbi cihaz olarak kabul edilmektedir. Özellikle implantlarla çok sıkı ilişkisi olan ortopedi ve travmatoloji uzmanlarının pratik hayatta geliştirdikleri ve tasarladıkları cihazlar bulunmaktadır. Keza cerrahi aletler için de benzer durum söz konusudur. Bu konuda ortopedi ve travmatoloji uzmanları oldukça başarılı bir konumda yer almaktadır. CE işaretine sahip ürünler Avrupa Birliği üye ülkeleri arasında serbest dolaşım imkânı sağlamaktadır. Makalemizde tıbbi cihazların tasarımından sonra nasıl bir sürecin işlediği hakkında bilgi verilmesi hedeflenmiştir.

Anahtar sözcükler: tıbbi cihaz; ortopedik implant; CE belgelendirme; MDR, Tibbi Cihaz Tüzüğü
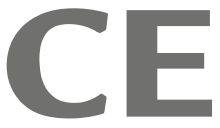
(Conformité Européenne) işareti Avrupa Birliği'nin ürünlerin serbest dolaşımını sağlayabilmek amacıyla 1985 yılında oluşturduğu sağlık ve güvenlik işaretidir ve Avrupa Topluluğu direktiflerine uygunluğu belirtmek üzere kullanılmaktadır. Bu yüzden CE işareti bulunmayan bir ürünün Avrupa Birliği pazarına girebilmesi mümkün olamamaktadır. Dolayısıyla üreticilerin bu yayınlanan direktiflere uygun olarak ürün üretmeleri artık elzem olmaktadır.

CE işareti kalite simgesi özelliğinden ziyade o ürünün Avrupa Topluluğu direktiflerinin tümüne uygun olduğunu göstermektedir. Bu direktifler ürünün performans özellikleri ve kalitesine yönelik şartlardan ziyade ürün güvenliğine yönelik şartları öngörmektedir. TSE belgelendirme ise ürünün performans ve kalite kriterlerini ve üretim yerinin yeterliliğini değerlendiren bir belgelendirmedir. Dolayısıyla CE ve TSE birbirine alternatif olarak değerlendirilmemelidir.
One of the most important criteria that distinguish a medical device from a medicament is its mechanical effect versus the chemical effect of the medicament. The current definition classifies orthopedic implants and surgical instruments as medical devices. Orthopedists, who practically have a close relationship with implants, had developed or designed many medical devices and surgical instruments. Orthopedists are in a very successful position in this field. Products with the CE mark provide free movement opportunities among European Union member countries. In our article, we aimed to clarify the necessary processes following medical device design.

Key words: medical device; orthopedic implant; CE certification; MDR, Medical Device Regulation

CE işaretine sahip ürünler Avrupa Birliği üye ülkeleri arasında serbest dolaşım imkânı sağlamaktadır. Benzer durum tıbbi cihazlar için de geçerlidir. Üretici CE işaretini ürüne koymak veya konulmasını temin etmek suretiyle ilgili düzenlemelere uygunluğunun kendi sorumluluğunda olduğunu ve ürünün gerekli tüm uygunluk değerlendirme işlemlerine tabi olduğunu beyan etmiş sayılmaktadır. ${ }^{[1]}$

Illaç ya da beşeri tıbbi ürün mevzuatta hastalığı tedavi etmek veya önlemek, bir teşhis yapmak veya fizyolojik fonksiyonu düzeltmek, düzenlemek veya değiştirmek amacıyla insana uygulanan doğal veya sentetik kaynaklı etkin madde/maddeler kombinasyonu olarak tanımlanmaktadır. ${ }^{2]}$

Tıbbi cihaz ile ilacı ayıran en önemli kriterlerden birisi ilacın genellikle farmakolojik, immünolojik ve metabolik etkisinin olması, cihazların ise genellikle fiziksel bariyer ve mekanik etkisinin olmasıdır.

- İletişim adresi: Op. Dr. Serdar Şirazi, Florya Plaza, Şenlikköy Mah. Eski Halkalı Cad., No: 3, K: 2, D: 25 B. Florya, Bakırköy, İstanbul Tel: 0536 - 6811187 e-posta: drserdarsirazi@yahoo.com ORCID iD: 0000-0002-2155-1894

- Geliș tarihi: 19 Kasım 2020 Kabul tarihi: 2 Aralık 2020 
Bir ürünün tıbbi cihaz olması için belirli kriterlere sahip olması gerekmektedir;

- Bir hastalığın tanı, tedavi veya önlenmesinde kullanılması

- Kullanıldığı alanlarda fiziksel veya mekanik etkisinin olması

Kozmetik ürün ise; insan vücudunun dış kısımlarına yani epidermis, tırnak, diş, saç, dudak ve dış genital organlarına uygulanmak üzere hazırlanmış, tek veya temel amacı bu kısımları temizlemek, koku vermek, görünümünü değiştirmek, korumak için kullanılan madde veya karışımları ifade eder. ${ }^{[3]}$

Mevzuata göre tıbbi cihaz; insanda kullanıldıklarında asli fonksiyonunu farmakolojik, immünolojik veya metabolik etkiler ile sağlamayan fakat fonksiyonu yerine getirirken bu etkiler tarafindan desteklenen ve insan üzerinde;

- Hastalığın tanısı, önlenmesi, izlenmesi, tedavisi veya hafifletilmesi ya da,

- Yaralanma veya sakatlığın tanısı, izlenmesi, tedavisi, hafifletilmesi veya mağduriyetin giderilmesi ya da,

- Anatomik veya fizyolojik bir işlevin araştırılması, değiştirilmesi veya yerine başka bir şey konulması ya da,

\section{- Doğum kontrolü}

amacıyla kullanılmak üzere imal edilmiş, tek başına veya birlikte kullanılabilen, imalatçısı tarafından özellikle tanı ve/veya tedavi amaçılı kullanılmak üzere imal edilmiş ve tıbbi cihazın amaçlanan işlevini yerine getirebilmesi için gerekli olan yazılımlar da dahil, her türlü araç, alet, teçhizat, yazılım, aksesuar veya diğer malzemeler olarak tanımlanmıştır. ${ }^{[4]}$

Tıbbi cihazlar kullanım amaçlarına ve şartlarına uygun olarak kullanıldığında hastaların klinik durumunu veya güvenliğini, kullanıcıların veya gerektiğinde diğer şahısların sağlığını veya güvenliğini tehlikeye düşürmeyecek şekilde tasarlanmalı ve üretilmelidir. ${ }^{[5]}$ Elbette ki tıbbi cihazların istenmeyen yan etkilere bağlı oluşturacağı riskin cihazdan beklenen performanslara kıyaslandığında kabul edilebilir olmalıdır.

Ortopedi ve travmatolojide kullanılan implantlar ve cerrahi aletler de mevcut tanıma girdiği için tıbbi cihaz olarak kabul edilmektedir. Özellikle implantlarla çok sıkı ilişkisi olan ortopedi ve travmatoloji uzmanlarının pratik hayatta geliştirdikleri ve tasarladıkları oldukça fazla tıbbi cihaz bulunmaktadır. Keza cerrahi aletler için de benzer durum söz konusudur. Bu konuda ortopedi ve travmatoloji uzmanları oldukça başarılı bir konumda yer almaktadır. Makalemizde tıbbi cihazların tasarımından sonra nasıl bir sürecin işlediği hakkında bilgi verilmesi hedeflenmiştir.

Tıbbi cihazlar kullanıldıkları yere, süreye ve yaptığı fonksiyonabağlıolaraksınıflandırııılar. Sınıflandırmada yine tıbbi cihazın bir beşeri ürün ile kombine kullanılması, hayvan kaynaklı veya insan kaynaklı bir ürün içerip içermediğine göre de değişmektedir.

Aktif tıbbi cihaz tanımı da yine mevzuatta yer çekiminin ya da insan vücudunun doğal olarak oluşturduğu enerji haricinde herhangi bir elektrik enerjisi veya güç kaynağıyla çalışan tıbbi cihazları tanımlamaktadır. Vücuda yerleştirilebilir aktif tıbbi cihaz ise tamamı veya bir kısmı tıbbi veya cerrahi bir müdahale ile insan vücuduna ya da doğal bir vücut girişine veya boşluğuna yerleştirilen ve yerleştirildiği yerde kalması gereken aktif tıbbi cihazı ifade etmektedir. ${ }^{[6]}$ Ortopedi ve travmatolojide omurga deformitelerinde kullanılan manyetik rod ve ekstremite deformitelerinde kullanılan uzayabilen implantlar bu kapsamda değerlendirilebilecektir.

Elbette öncelikle ürünün mevcut mevzuata göre tıbbi cihaz olup olmadığı irdelenmeli, tıbbi cihaz olduğu kanaatine varıldıktan sonra sınıfının ne olduğu ortaya çıkarılmalıdır. Bunun nedeni her tıbbi cihazın aynı sürece tabi olmamasıdır.

Sınıflandırma süre esasına göre;

Geçici süreli: 60 dakikadan az bir sürede ve devamlı kullanılması amaçlanan tıbbi cihazlar,

Kısa süreli: 30 günden az ve sürekli kullanılması amaçlanan tıbbi cihazlar,

Uzun süreli: Normalde 30 günden fazla ve sürekli kullanılması amaçlanan tıbbi cihazlar olarak sınıflandırıırlar.

Tıbbi cihazlar ayrıca teşkil ettiği risk durumuna göre;

- Sinıf I

- Sinıf Ila

- Sinif IIb

- Sinıf III

olarak sınıflandırılırlar.

Protezler, omurga implantları Sınıf III olarak sınıflandırılmaktadır. Çiviler, plaklar, vidalar Sınıf Ilb olarak klasifiye edilmiştir.

Üretilmesi planlanan bir tıbbi cihazın döngüsü;

- Tasarım

- Belgelendirme

- Üretim

- Kayıt

- Satış

- Kullanım

- Kullanım dışı bırakma

olarak sıralanabilir. ${ }^{[4]}$ 


\section{Tasarım}

Tıbbi cihazlar kullanım amaçlarına ve şartlarına uygun kullanıldığında hastaların ve kullanıcıların sağlığını ve güvenliğini tehlikeye düşürmeyecek şekilde tasarlanmalı ve üretilmelidir. Ürünün güvenliğine yönelik kimyasal ve fiziksel analizler, raf ömrü, biyouyumluluk çalışmaları, klinik değerlendirme raporu, klinik araştırma gibi çalışmaların belgelendirme sürecinden önce yani tasarım ve prototip üretim aşamasında yapılmış olması gerekmektedir. ${ }^{[5]}$

İmalatçının veya tasarımcının tıbbi cihazların tasarım ve yapımında benimsediği çözümlerin genel kabul görmüş teknik yöntemler içermeli ve güvenlik prensiplerine uygun olmalıdır.

Tıbbi cihazın tasarımında cihazın ergonomik özelliklerinden ve cihazın kullanılması amaçlanan ortamdan kaynaklanabilecek hatalı kullanım riskinin mümkün olduğunca azaltılması (hasta güvenliğine yönelik tasarım) ve cihazı kullanması düşünülen kişilerin teknik bilgisi, deneyimi, öğrenim durumu ve mümkünse tıbbi ve fiziksel durumunun göz önüne alınması gerekmektedir. ${ }^{[6]}$

Bir cihaz tasarlandıktan sonra bu cihazın piyasada kullanılması için belgelendirilmesi gerekmektedir. Ancak belgelendirme sonunda cihazın satışı yapılabilmektedir.

Bir ürünün piyasaya arz edilebilmesi için ilgili teknik düzenleme veya yapılan düzenlemelerde ürün için öngörülen uygunluk değerlendirme işlemlerine tabi tutulması ve bu işlemlerin olumlu sonuçlanması gerekmektedir. ${ }^{[7]}$

\section{Belgelendirme}

Tıbbi cihaza ait bir teknik dosya üretici tarafından hazırlanmış olması gerekmektedir. Teknik dosya içinde tıbbi cihazın klinik değerlendirilmesi önemli bir yer teşkil etmektedir. Teknik dosya ürünle ilgili tüm bilgileri içermekte ve ürünle ilgili satış sonrası süreçte de elde edilen bilgilerle güncellenen bir dosya özelliği göstermektedir. Klinik değerlendirme sınıf ayırımı olmaksızın bütün tıbbi cihazlar için gerekmektedir ve teknik dosyanın içinde önemli bir konumda yer almaktadır. Dolayısıyla klinik faydası olmayan hiçbir cihaz piyasaya arz edilemeyecektir.

Belgelendirme sonunda tıbbi cihaza EC sertifikası (Examination Certificate) verilmektedir ve üretici bu EC sertifikasıyla birlikte cihazına CE simgesini alarak ilgili tıbbi cihazın kullanımını ve satışını yapabilecektir. Söz konusu belgelendirme onaylanmış kuruluşlar tarafından yapılmaktadır. Bu kuruluşlar üreticinin kendilerine verdikleri ürün ile ilgili dokümanları kendi bünyelerinde bulunan hekimler ve biyomedikal mühendisler tarafindan incelenerek gerekli kriterleri karşılayıp karşılamadığını değerlendirdikten sonra sertifikalandırmayı sağlayabilmektedirler.

Üretici risk yönetim sistemini oluşturmalı, bunun dâhilinde klinik araştırma, klinik değerlendirme ve piyasaya arz sonrası klinik takibin bileşeni olarak ele alınarak klinik değerlendirmeye yansıtılmalıdır. ${ }^{[8]}$ Dolayısıyla risk yönetim sistemi sürekli güncellenen bir dinamik bir yapıya sahip olacaktır. ${ }^{[4]}$

\section{Klinik değerlendirme}

Bütün tıbbi cihazların teknik dosyasında kapsamlı bir analize dayanan, ürünün olumsuz yönlerini de açıkça içeren bir klinik değerlendirme formu olmalıdır.

Uygunluk değerlendirme sürecinde; bir tıbbi cihazın temel gerekliliklere uygunluğunun gösterilmesi sırasında mevzuata uygun şekilde gerçekleştirildiğine dair bir klinik değerlendirme çalışması yer almalıdır. Tıbbi cihazın normal kullanım koşullarında fayda risk oranının kabul edilebilirliğine, yan etkilere ilişkin değerlendirme ve klinik verilere dayanmalıdır. Bu değerlendirme klinik değerlendirme olarak anılmaktadır

Bu çalışmada üretici, cihazın güvenlik ve performansıyla ilgili iddiaların, cihazın normal kullanım koşulları altında doğruluğunu kanıtlamayı hedefler. Genellikle bu çalışma ilgili tıbbi cihazın niteliklerine, kullanım amacına ve risklerine uygun olan klinik bilgilerin toplanmasını ve sunulmasını gerektirir. ${ }^{[4]}$

Yeterli düzeyde klinik veri güvenlik ve performans kanıtları, söz konusu cihazla veya eşdeğer cihazla ilgili yayınlanmış/yayınlanmamış klinik deneyimlerin kritik değerlendirmesi, risk analizleri, klinik araştırma ve cihazla ilgili yapılan testlerden oluşmaktadır.

Klinik veri değerlendirmesinin amacı ürünü destekleyen kaynakları ve ürüne karşı olan kaynakları belirleyerek yorumlamaktır. Fayda - risk tespiti imalatçının beyan ettiği kullanım amacına uygun olarak kullanıldığında cihazın amaçlanan kullanımı ile muhtemel tüm fayda ve risk değerlendirmelerinin analizi olarak bilinmektedir.

Eğer üretilmesi planlanan ürünün benzeri hali hazırda piyasada bulunmakta ise o zaman bu iki cihaz arasından eşdeğer cihaz kriterlerinin uyması halinde ayrıca bir klinik araştırma yapılmasına gerek kalmayacaktır. Dolayısıyla daha önce piyasaya arz edilen tıbbi cihaza ait literatür ve yapılmış klinik araştırmalar üretilmesi planlanan tıbbi cihaz için de kullanılabilecektir. ${ }^{[4]}$

Klinik değerlendirme piyasaya arz sonrası gözetim ve denetimden elde edilen veriler doğrultusunda sürekli olarak güncellenmelidir. 
Teknik dokümantasyonun içinde tıbbi cihaz olmasına ilişkin gerekçe, risk sınıfı, imalatçı tarafından temin edilen tanıtım materyalleri, güvenlik ve klinik performans özeti, tasarım ve imalat bilgileri, genel güvenlik ve performans bilgileri, fayda-risk analizi, piyasaya arz sonrası gözetim planı (Post-Market Surveillance -PMS) piyasaya arz sonrası klinik takip (Post-Market Clinical Follow-up -PMCF) içeren teknik dokümanları oluşturup onaylanmış kuruluşa vermek durumundadır.

Klinik değerlendirme raporunda:

- Ürünle ilgili genel bilgiler

o Cihaz adı ve kodu

○ Üretici bilgileri

- Cihaz tanımı ve kullanım amacı

- Terapötik endikasyonlar ve iddialar

- Klinik ön bilgi, mevcut bilgi ve en son teknoloji

- Literatür tarama metodu ve mevcut bilgi ve teknoloji

○ Geçerli standartlar ve kılavuzlar

○ Klinik gereklilikler

- Klinik riskler

- İlgili ürünün klinik verilerinin değerlendirmesi

- Değerlendirmenin türü

○ Eşdeğerlik gösterimi

- İmalatçı tarafından üretilen ve saklanan klinik veriler

○ Literatürden elde edilen klinik veriler

- Klinik verilerin özeti ve değerlendirmesi

- Klinik verilerin analizi

- Güvenlik şartları

- Kabul edilebilir risk/fayda profilleri ve yan etkiler

o Performans

- Varılan sonuçlar

- Referanslar

olmalıdır. ${ }^{[4]}$

\section{Klinik araştırma}

Yeni tanı ve/veya tedavi yöntemlerinin geliştirilmesi için bilimsel olarak yapılması gereken çalışmalara klinik araştırmalar denilmektedir. Ayrıca yeni bir cihazın güvenliğinin ve etkinliğinin gösterilmesi için belli bir popülasyon üzerindeki uygulamaların bilimsel analizi ile değerlendirilmesi ve bu değerlendirme sonucunda fayda risk analizinin belli bir seviyede olması ile cihazın kullanılmasının uygun olacağını gözler önüne seren bir yoldur.
Mevcut klinik verilere tam olarak dayandırılamayan tıbbi cihazlar için klinik araştırma yapılmak durumundadır.

Klinik araştırmalar 1964 yılında Finlandiya'nın Helsinki şehrinde yapılan 18. Dünya Tıp Kurulu'nda kabul edilen Helsinki Bildirgesi'ne göre yapılmalıdır. İnsan sağlığını korumaya yönelik bütün tedbirlerin Helsinki Bildirgesi çerçevesinde uygulanması zorunludur. ${ }^{[9]}$

Klinik araştırma güncel, bilimsel ve teknik bilgileri yansıtan bir plana göre uygulanmalı ve imalatçının tıbbi cihaza ilişkin iddialarını doğrulayıcı ve reddedici şekilde belirlenmelidir. Klinik araştırmalar sonuçların bilimsel geçerliliğini garantileyen yeterli sayıda gözlem içermelidir. ${ }^{[9]}$

Klinik araştırmada gönüllülere araştırma hakkında yapılacak ayrıntılı, anlaşılır bilgilendirme ve sonunda alınacak olur formunun olması oldukça önem ihtiva etmektedir. ${ }^{[10]}$ Ayrıca klinik araştırma gönüllülerine sigorta yaptırılması da yasal bir zorunluluktur.

Tıbbi cihaz klinik araştırması ise bir veya daha fazla merkezde, tıbbi cihazın güvenlik, etkinlik veya performansını değerlendirmek için gönüllüler üzerinde yürütülen sistematik araştırma veya çalışmaları ifade etmektedir. ${ }^{[11]}$ Klinik araştırmayı hekimin yapması gerekmektedir.

Bütün tıbbi cihazlar için yapılması gereken klinik araştırma için etik kurul başvurusunun ve etik kurul onayının olması gerekmektedir.

Araştırmanın hastaların güvenliğini sağlaması, takibinin ve gerekli durumlarda müdahalenin yapılabilmesine imkân sunması açısından üniversite hastanelerinde veya eğitim araştırma hastanelerinde yapılması gerekmektedir. Ayrıca bu hastanelerin koordinatör hastane olması halinde özel hastanelerde de yapılabilmektedir. Ortopedi ve travmatoloji hekimi tarafindan yapılması gerekli olan implant klinik araştırmasının olumsuz durumları da eksiksiz olarak kaydedilmeli ve durum Sağlık Bakanlığı'na bildirilmelidir.

Klinik araştırma protokolü araştırıcı tarafindan hazırlanıp “ilyi Klinik Uygulamaları Kılavuzu (IKU)"na gerekli diğer formlar ve araştırma broşürü eklenerek etik kurul başvurusu yapılır. Tıbbi cihaz klinik araştırmasının etik kurulun çalışmayı onaylamasıyla birlikte yetkili kurum (T.C. Sağlık Bakanlığı Türkiye İlaç ve Tıbbi Cihaz Kurumu) onayı gerekmektedir. Hatta daha önce yapılan başvurular olumsuz sonuçlanmış ise o etik kurul kararları da kuruma başvurularda dosyaya konulmalıdır. Kurum usulen uygun yapılan başvuruları 60 gün içinde karara bağlamaktadır. Etik kurul kararına karşı itirazlar kurum bünyesinde oluşturulan Klinik Araştırmalar Danışma Kurulu tarafından değerlendirilmektedir. ${ }^{[9]}$ 
Tıbbi cihaz klinik araştırmasının her türlü hukuki ve mali sorumluluğu araştırmayı yapan kişiye, destekleyicisine ve araştırma kuruluşuna aittir. ${ }^{[12]}$

Ortopedi ve travmatolojide kullanılan tüm implantlara klinik araştırma yapılması gerekmektedir. Ancak mevcut kullanılan implanta eşdeğer bir ürün ise eşdeğerliğin teknik, biyolojik ve klinik olarak tam gösterilmesi şartıyla klinik araştırma yapılmayabilmektedir. Teknik eşdeğerlik implantın benzer tasarıma ve kullanım şartlarına sahip olduğunu, biyolojik eşdeğerlik benzer temas türü ve süresiyle, klinik eşdeğerlik ise vücudun aynı bölgesinde benzer bir popülasyonda benzer hastalıklarda ve klinik durumda kullanılması ile olmaktadır. Üretici tıbbi cihazın eşdeğer olduğunu her yönüyle bilimsel olarak ortaya koyabilmelidir.

Tüm bunların ışığında ortopedi ve travmatolojide kullanılan implantın üreticisi ve/veya tasarımcısı tarafından belirlenen performans hedeflerine ulaştığını göstermek, beklenen faydanın sağlandığını doğrulamak hasta için kabul edilebilir bir risk oluşturup oluşturmadığını tespit etmek ve cihaza ait belirlenen amacının dışında bir özelliğinin varlığını tespit etmek için klinik araştırma yapılması gerekmektedir.

\section{Onaylanmış kuruluş}

Onaylanmış kuruluş; Bir teknik düzenleme kapsamında uygunluk değerlendirme faaliyetinde bulunmak üzere Türkiye Illaç ve Tıbbi Cihaz Kurumu tarafindan mevzuatta belirlenen esaslar doğrultusunda görevlendirilen ve Avrupa Birliği Komisyonuna bildirilen kuruluştur. ${ }^{[13]}$

Tarafsızlığını garanti eden onaylanmış kuruluş, ortopedi ve travmatolojide kullanılan implant alanında yeterli teknik bilgiye sahip olmalı, değerlendirme ve doğrulama işlemlerini mesleki etik kurallar çerçevesinde yapmalıdır. ${ }^{[10]}$

Onaylanmış kuruluş teknik şartlara uymayan ürünleri tespit ettiklerinde üreticiden gerekli düzenlemeleri yapmasını isteyebilmekte, keza uygunluk belgesi düzenledikten sonra da yapacakları gözetim sırasında ürünün uygunsuzluğunu tespit etmeleri durumunda üreticiden gerekli değişiklikleri yapmalarını isteyebilmekte, belgeyi askıya alabilmekte hatta geri çekebilmektedir.

Onaylanmış kuruluş klinik öncesi literatür taraması, klinik öncesi testlerden örneğin laboratuvar testleri, simüle edilmiş kullanım testleri, bilgisayar modellemeleri, hayvan modellerinin kullanımı, spesifik biyolojik riskler, risk yönetim süreci, piyasaya arz sonrası gözetim (PMCF) gibi parametreleri değerlendirmektedir.

Onaylanmış kuruluş karar verirken Avrupa Tıbbi Ürünler Değerlendirme Ajansının (EMEA) görüşünü göz önünde bulundurur. EMEA'nın bilimsel görüşü olumlu değilse onaylanmış kuruluş sertifikayı vermeyebilir ${ }^{[14]}$.
Onaylanmış kuruluş uygunluk değerlendirmesini yaptıktan sonra ürüne ait EC sertifikası düzenler. EC sertifikası düzenlenmiş tıbbi cihaza CE işareti konulabilecektir. Bu sayede tıbbi cihazın seri üretimi yapılabilecek. Onaylanmış kuruluş ortopedi ve travmatolojide kullanılacak implantın hangi yönetmelik kapsamına girdiğini belirleyerek değerlendirmesini yapar. Düzenlediği, değişiklik - ekleme yaptığı, askıya aldığı, iptal ettiği veya geri çektiği tüm belgeler hakkında Türkiye ilaç ve Tıbbi Cihaz Kurumu'na bilgi vermek durumundadır.

\section{Kayıt}

Ürünün piyasaya arz edilebilmesi için önce Türkiye İlaç ve Tıbbi Cihaz Kurumu'ndan "Tıbbi cihaz satış merkezi yetki belgesi” alınmalı, akabinde yine aynı kurum tarafından tutulan Ürün Takip Sistemine (ÜTS) firma, belge ve ürün kayıt işlemlerinin gerçekleştirilmesi gerekmektedir.

\section{Üretim ve Satış}

Kayıt işlemi gerçekleştikten sonra tıbbi cihaz üretilebilecek ve piyasaya arz edilebilecektir. Tıbbi cihaz üreticilerinin piyasaya arz sonrası sorumlulukları devam etmektedir. Ortopedi ve travmatoloji alanında kullanılan implantlar sadece sağlık çalışanı tarafindan kullanılacağı için topluma reklam edilmesi mevzuatta yasaklanmıştır. Reklam tüm kamuoyuna yapılacak ürünler için geçerli bir uygulamadır. Bu konuda üretici ve/veya tasarımcı sadece implantı kullanan kesime yani sağlık mensubuna tanıtım yapabilecektir. ${ }^{[15]}$ Tanıtım doğrudan ziyaret, bilimsel toplantılar düzenleme veya desteklemeyle ve bilimsel dergilerde yer alabilecektir.

Ortopedi ve travmatolojide kullanılan implantlar tek kullanımlık üretildiği için kullanım süresince test, kontrol ve kalibrasyon faaliyetlerine tabi tutulmamaktadır. Üretilen diğer tıbbi cihazlar için bu konuda yönetmelik yayınlanarak düzenlenmiştir. ${ }^{[16]}$

Steril tıbbi cihazlar tek kullanımlık ambalajlarda piyasaya arz edildiğinde, depolama ve nakil aşamalarında koruyucu ambalajı açılıncaya kadar steril kalmasını sağlayacak uygun yöntemlere göre paketlenmelidir. ${ }^{[17]}$

\section{Kullanım}

Ortopedi ve travmatoloji alanındaki implantın kullanım esnasında herhangi bir olumsuzlukla karşılaşıldığı durumda durumun raporlanarak kuruma bildirilmesi gerekmektedir. Bu tasarımcı, üretici, kullanıcı olan hekim ve hasta açısından üzerinde durulması gereken bir konudur. Olumsuzluk Türkiye İlaç ve Tıbbi Cihaz Kurumu "Imalatçı olumsuz olay rapor formu" doldurularak yapılmaktadır. 
Üretici piyasaya arz sonrası klinik takibi (PMCF) yapmalı ve tutulan formu klinik değerlendirmede güncellemelidir. İmalatçı cihazın beklenen kullanım ömrü süresince güvenliğini ve performansını teyit etmek için ve tanımlanmış risklerin kabul edilebilirliğini gerçek kanıtlarla ortaya koymak için piyasada kullanılan ortopedi ve travmatoloji alanındaki implantın klinik verilerini aktif olarak toplar ve değerlendirir. Bu sayede önceden bilinmeyen yan etkiler de değerlendirilmiş olunmakta, önleyici-düzeltici tedbirler alınabilmekte ve tasarımla ilgili değişiklikler planlanabilmektedir.

\section{Kullanım Dışı Bırakma}

Yönetmeliklere uygun olmayan durumun tespit edilmesi halinde ürünün imalatçısı veya yetkili temsilcisi sorumlu olmaktadır.

Yetkili temsilci; imalatçısı tarafından açık olarak yetkilendirilmiş olan ve imalatçı adına bu yönetmelikte yer alan yükümlülükleri yerine getirmek üzere hareket eden ve Türkiye îlaç ve Tıbbi Cihaz Kurumu ve kuruluşlar tarafından muhatap alınan Türkiye'de yerleşik gerçek veya tüzel kişi olarak belirlenmiştir. Sağlık Bakanlığı kanunen kendisine verilen yetkiler çerçevesinde ürününün yasaklanmasına karar verebilmekte, piyasadan geri çekilmesine ve zarar görenlerin zararının tazmini için sorumlular hakkında yasal işlem başlatabilmektedir. Bu konuda üretici ile birlikte yetkili temsilcinin de sorumluluğu bulunmaktadır.

\section{YENI YÖNETMELIK; MDR}

Avrupa Birliği Komisyonu tarafindan hazırlanan (AB) 2017/745 sayılı Avrupa Topluluğu Tıbbi Cihaz Yönetmeliği (Medical Device Regulation -MDR) 25.05.2017 tarihinde Avrupa Birliği Resmi Gazetesi'nde yayımlanmıştır. İlgili yönetmelik 26.05.2020 tarihinde yürürlüğe girecekken bu tarih pandemi nedeniyle 1 yıl ertelenmiştir.

Halen yürürlükteki Avrupa Topluluğu Tıbbi Cihaz Direktifi (Medical Device Directive -MDD) 60 sayfa 23 madde ve 12 ekten oluşmaktayken MDR 175 sayfa 123 madde ve 16 ekten oluşmaktadır.

Yeni tıbbi cihaz tüzüğünde sınıflandırma, uygunluk değerlendirme aşamaları ve klinik değerlendirme gibi konularda yeni maddeler eklenmiştir. Özellikle Sınıf 1 tıbbi cihazların sınıflandırması üst sınıfa çıkarılarak değişmiş, ancak ortopedi ve travmatoloji alanında kullanılan implantların sınıflanmasında önemli bir değişiklik olmamıştır. Tıbbi cihazların yazılım programları da MDR kapsamında ele alınmıştır. Cerrahi aletler sınıf $1 r$ (tekrar kullanılabilir) olarak sınıflandırılmıştır. Daha önce bu aletlere CE belgesi alınması gerekmemekteyken, sadece uygunluk beyanı ile piyasaya arz edilebilmekteyken artık EC sertifikası alınması gerekecektir. Yeni yönetmelikte tıbbi cihazların temizlik, dezenfeksiyon ve sterilizasyon kapsamının üreticinin sorumluluğunda olduğuna vurgu yapılmaktadır. Hâlihazırda yürürlükte olan Avrupa Topluluğu Tıbbi Cihaz Direktifi'nde (MDD) tıbbi cihazların izlenebilirliğine ilişkin hükümler yer almamaktayken, imalatçıуa ve cihaza özgü tekil cihaz kimliği (Unique Device Identification -UDI) MDR kapsamında yer almaktadır. Bu sistemle birlikte tıbbi cihazlara ait olumsuz olayların raporlanması, düzeltici faaliyetlerin ve geri çekmelerinin kolaylaştırılması, cihaz tedarik zincirinin takibi gibi işlemlerin daha iyi bir şekilde yürütülmesi hedeflenmektedir. UDI numarasının alınması üretici tarafından onaylanmış kuruluşa başvurudan önce olmalıdır.

Yine sınıf III'e dahil olan ortopedi ve travmatoloji bölümünde kullanılan implantların değerlendirilmesinde onaylanmış kuruluşlara Avrupa Birliği dahilinde kurulan "Uzman heyet"e raporların gözden geçirilmesi için danışma zorunluluğu getirilmiştir. [18]

Tıbbi cihaz üreticisinin birlik içerisinde yerleşik olmaması durumunda bir yetkili temsilcisinin olması istenmektedir. Yetkili temsilci imalatçı adına tüzük kapsamındaki yükümlülükleri yerine getirecektir. Yetkili temsilci imalatçıdan yazılı bir vekâletname alarak birlik içerisinde yerleşik bulunan gerçek veya tüzel kişi olabilmektedir. ${ }^{[19]}$

Yeni yönetmelikte kullanııların yani hekimlerin yaralanma risklerini olabildiğince azaltan tasarımların olması gerektiği, kolay ve güvenli kullanıma imkân sağlaması ve mikrobiyal maruziyeti mümkün olduğunca azaltan tasarımların olması gerektiğinin üzerinde durulmaktadır.

MDR ile birlikte EUDAMED (European Databank on Medical Devices) olarak adlandırılan piyasadaki tıbbi cihazları, onaylanmış kuruluşları, sertifikaları, klinik araştırmalar, piyasa gözetim ve denetimleri ile ilgili bilgilerin yer aldığı bir veri tabanı oluşturulacaktır. İmalatçı güvenlik ve klinik performans özeti, hedeflen kullanıcı ve ilgili olması halinde hastalar için anlaşılır bir şekilde hazırladığı belgeleri EUDAMED aracılığıyla kamuya açık tutacaktır. Bu veri tabanı sayesinde sağlık profesyonelleri tıbbi cihazlarla ilgili bilgiye doğrudan ulaşabilecektir.

İmalatçılar mevzuata uyumdan sorumlu olacak 4 yıllık mesleki tecrübeye sahip bir uzman (tıp eczacılık, diş hekimliği vb. fakültelerden mezun) birisini bulundurmak zorunda kalacaktır. Küçük işletmeler uzman bulundurmayıp dışarıdan bu hizmeti alabilecektir. ${ }^{[20]}$

Onaylanmış kuruluşlardan sorumlu bir yetkili otorite ulusal düzeyde belirlenmiş olacaktır. Bu otorite ülkemizde Türkiye İlaç ve Tıbbi Cihaz Kurumu'dur. 
Cihazı piyasaya süren işletmeler ortopedi ve travmatoloji alanındaki implantları en az 15 yıl kime tedarik ettiklerini ve kimden tedarik aldıklarının kaydını tutmakla ve gerektiğinde Türkiye ilaç ve Tıbbi Cihaz Kurumu'na vermekle mükellef kılınmıştır.

Avrupa Topluluğu yeni tıbbi cihaz tüzüğünde getirilen bir madde ile üretici tıbbi cihazın neden olabileceği olumsuz durumlara karşı mali teminat sağlaması için gerekli tedbirleri alması istenmektedir. ${ }^{[21]}$

Yeni tıbbi cihaz yönetmeliğinde implante edilebilir cihaz tanımına insan vücuduna tamamen yerleştirilmesi ile veya uygulama sonrasında asgari 30 gün boyunca yerinde kalması amaçlanan cihazlar da ele alınmaktadır. ${ }^{[21]}$

Ortopedi ve travmatoloji alanındaki implantlar klinik araştırma amaçlı üretilmiş ise steril paketinin üzerinde "Klinik araştırmaya mahsustur" ibaresi, ısmarlama amaçlı ise "Ismarlama üretilen cihaz" ibaresi yazmalıdır.

İmalatçılar hastalara implante edilen cihazlar için "Implant kart" sağlayacak, bu kartla cihazın tanımı, adı, seri numarası, lot numarası UDI ve imalatçısı, cihazın beklenen ömrü ve gerekli takiplerle ilgili bilgiler hastanın anlayacağı bir şekilde yer alacaktır.

Yeni yönetmelikle vijilans; takiplerde hastanın veya kullanıcının ya da başka bir kişinin ölümüne, sağlık durumunda geçici yada kalıcı ciddi bozulmaya ve ciddi kamu sağlığını tehdide yol açması halince durum derhal raporlanarak kuruma bildirilmelidir. Ergonomik özellikleriden kaynaklanan kullanım hataları da olumsuz olay kapsamında değerlendirilmiştir. İmalatçı bu durumda derhal "Saha Güvenliği Düzeltici Faaliyeti (Field Safety Corrective Action -FSCA)" adı altında olumsuz olay riskini önlemek, azaltmak amacıyla düzeltici faaliyetleri yürütmekle mükelleftir.

Onaylanmış kuruluşlar üreticiye habersiz denetim yapabilecektir. İmplantlar için uzmanlar kurulu onaylanmış kuruluşun bu cihazları danışacağı bir kurum olarak yer almıştır.

Yeni yönetmeliğin Mayıs 2021 tarihinde yürürlüğe gireceği düşünüldüğünde tasarım aşamasında olan ortopedi ve travmatoloji alanındaki implantların yeni yönetmeliğe göre hazırlanması gerekeceği göz önünde bulundurulmalıdır. Söz konusu yeni yönetmeliğin (MDR) ortopedi ve travmatoloji kapsamındaki implantların üretiminin ve belgelendirilme sürecinin daha kapsamlı bir değerlendirmeye tabi tutulacağı, satış sonrası gözetim parametrelerinin artması dolayısıyla imalatçı tarafindan oluşabilecek olumsuz olaylara karşı hukuki sorumluluğunu yerine getirmek amacıyla bir maddi kaynak yaratacak olması ve tüm bunların ışı̆̆ında hasta ve kullanıcı hekimin güvenliğinin daha da ön plana alınmasının sonucunu doğuracağı aşikardır.

\section{KAYNAKLAR}

1. CE İşareti Yönetmeliği, Madde 9. 23.02.2012 tarihli ve 28213 sayılı Resmi Gazete. https://www.mevzuat.gov.tr

2. Beşeri Tıbbi Ürünlerin Tanıtım Faaliyetleri Hakkında Yönetmelik, Madde 4. 03.07.2015 tarihli ve 29405 sayılı Resmi Gazete. https://www.mevzuat.gov.tr

3. Kozmetik Kanunu. Sayı: 5324 sayı. Kabul Tarihi: 24.03.2005. Resmi Gazete Tarihi 30.03.2005. https://www.mevzuat.gov.tr

4. Tıbbi Cihaz Yönetmeliği, Ek 1. 07.06.2011 tarihli ve 27957 sayılı Resmi Gazetede. https://www.mevzuat.gov.tr

5. Vücuda Yerleştirilebilir Aktif Tıbbi Cihazlar Yönetmeliği, Madde 3. 07.06.2011 tarihli ve 27957 sayılı Resmi Gazete. https://www.mevzuat.gov.tr

6. CE İşareti Yönetmeliği, Madde 8. 23.02.2012 tarihli ve 28213 sayılı Resmi Gazete. https://www.mevzuat.gov.tr

7. Tıbbi Cihaz Tüzüğü Madde 1/33 (AB) 2017/745 sayılı. https://www.mevzuat.gov.tr

8. Vücuda Yerleştirilebilir Aktif Tıbbi Cihazlar Yönetmeliği Ek. 07. 07.06.2011 tarihli ve 27957 sayılı Resmi Gazete. https:// www.mevzuat.gov.tr

9. Tıbbi Cihaz Klinik Araştırmaları Yönetmeliği, Madde 27. 06.09.2014 tarihli 29111 sayılı Resmi Gazete. https://www. mevzuat.gov.tr

10. Uygunluk değerlendirme Kuruluşları ve Onaylanmış Kuruluşlar Yönetmeliği. 23.02.2012 tarihli 28213 sayılı Resmi Gazete. https://www.mevzuat.gov.tr

11. Tıbbi Cihaz Klinik Araştırmaları Yönetmeliği, Madde 5. 06.09.2014 tarihli 29111 sayılı Resmi Gazete. https://www. mevzuat.gov.tr

12. Tıbbi Cihaz Klinik Araştırmaları Yönetmeliği, Madde $4 / r$. 06.09.2014 tarihli 29111 sayılı Resmi Gazete. https://www. mevzuat.gov.tr

13. Tıbbi Cihaz Yönetmeliği, Ek 2. 07.06.2011 tarihli ve 27957 sayılı Resmi Gazete. https://www.mevzuat.gov.tr

14. Tıbbi Cihaz Satış, Reklam ve Tanıtım Yönetmeliği. 15.05.2014 tarihli ve 29001 sayılı Resmi Gazete. https:// www.mevzuat.gov.tr

15. Tıbbi Cihazların Test, Kontrol ve Kalibrasyonu Hakkında Yönetmelik. 25.06.2015 tarihli ve 29397 sayılı Resmi Gazete. https://www.mevzuat.gov.tr

16. (AB) 2017/745 Sayılı Tıbbi Cihaz Tüzüğü, Madde 2/5. https://www.titck.gov.tr

17. (AB) $2017 / 745$ Sayılı Tıbbi Cihaz Tüzüğü, Madde 1/56 https://www.titck.gov.tr

18. (AB) $2017 / 745$ Sayılı Tıbbi Cihaz Tüzüğü, Madde 2/32. https://www.titck.gov.tr

19. (AB) $2017 / 745$ Sayılı Tıbbi Cihaz Tüzüğü, Madde 15/1. https://www.titck.gov.tr

20. (AB) $2017 / 745$ Sayılı Tıbbi Cihaz Tüzüğü, Madde $1 / 31$. https://www.titck.gov.tr

21. (AB) $2017 / 745$ Sayılı Tıbbi Cihaz Tüzüğü, Madde $2 / 5$. https://www.titck.gov.tr 